\section{The Estimation of Protein in the Cerebrospinal Fluid Using the M.R.C. Photometer}

\author{
J. G. ALEXANDER AND J. PARKES \\ From the Department of Pathology, Western General \\ Hospital, Hull
}

(RECEIVED FOR PUBLICATION MARCH 28, 1958)

In the communication by Yeoman (1955) it is stated that the proportion of cerebrospinal fluid to $3 \%$ aqueous salicylsulphonic acid is one to three when used to determine the protein content in the M.R.C. photometer. This method has been studied by comparing results using his method and results obtained by the micro-Kjeldahl method (King, 1951) on the same specimens. Twenty specimens were examined in which the levels were representative of all levels found in practice, i.e., normal, moderate increase, and marked increase. The results showed that the M.R.C. photometer method was fairly accurate if $1 \mathrm{ml}$. of cerebrospinal fluid was added to $4 \mathrm{ml}$. (not $3 \mathrm{ml}$.) of $3 \%$ salicylsulphonic acid. One of us (J. G. A.) communicated with Dr. Yeoman and he agreed that the proportions should have been one to four and not one to three. It was found, however, that the true protein level $(x)$ was slightly higher than the reading on the photometer $(y)$, the two being related by the equation $x=\frac{16 y+20}{15}$

When the protein concentration exceeds $120 \mathrm{mg}$./ $100 \mathrm{ml}$. it is necessary to dilute the cerebrospinal fluid with water because the curve is no longer linear above this value. The use of saline as a diluent gives increased readings.

\section{REFERENCES}

King, E. J. (1951). Micro-Analysis in Medical Biochemistry, 2nd ed., p. 46. Churchill, London.

\section{The "Normal Range" of the Prothrombin Time Estimated by Quick's Method}

\author{
G. I. C. INGRAM AND P. ARMITAGE \\ From the Louis Jenner Laboratory, St. Thomas's \\ Hospital and Medical School, and the Medical \\ Research Council's Statistical Research Unit, London \\ School of Hygiene and Tropical Medicine
}

(RECEIVED FOR PUBLICATION JUNE 26, 1958)

Armitage and Ingram (1958) have recently investigated some errors affecting Quick's prothrombin time. They found that the differences between the prothrombin times of normal persons were much greater than could be explained by the experimental error of the method, and that it was possible to devise a simple rule of thumb to express the amount by which a given "control " plasma might be expected to differ from another normal plasma.

Prothrombin times were measured on 56 differing pairs of normal plasmas, with four replicate readings from each sample. The standard deviation of the difference between mean times for the paired subjects was about $9 \%$ of the average of the prothrombin times of the pair. Experimental error would have contributed only some $2 \%$ to this figure, or rather less than one-quarter of the total standard deviation. A reduction in the number of replicate readings made on the two samples will appreciably increase the contribution of experimental error, but will not greatly increase the total standard deviation, which can therefore be taken to be about $9 \%$ of the average prothrombin time, irrespective of the number of readings. Had only two replicate readings been obtained instead of four, the error contribution would have risen only to $3 \%$ of the average prothrombin time, or one-third of the total standard deviation, in the above experiments.

This means, for example, that in 95 cases out of 100 two normal prothrombin times will differ by less than about $2 \times 9 \%$, or say one-fifth of their average (the rule is expressed in this way to be independent of the activity of the brain extract). In the control of anticoagulants, such small differences are clearly of no importance, but in the study of bleeding disorders and as a precautionary investigation, e.g., before needle biopsy of viscera, it may on occasion be useful to test borderline cases in this way.

It can usually be assumed that the patient's prothrombin time will differ materially from the control, if at all, only in one direction, e.g., it is often of no consequence if the patient's time is shorter than the control time. In this situation it may be said that only about once in 40 times, i.e., 2.5 times out of 100 , should a normal prothrombin time exceed the control 
TABLE FOR DETERMINING THE NORMAL RANGE OF THE PROTHROMBIN TIME

\begin{tabular}{|c|c|c|c|c|c|c|c|c|c|c|c|c|c|c|c|c|c|}
\hline \multirow{2}{*}{\multicolumn{2}{|c|}{$\begin{array}{c}\text { Frequency with which Tabulated } \\
\text { Timo would be Exceeded in Tests } \\
\text { on Paired Plasmas }\end{array}$}} & \multicolumn{16}{|c|}{ Control Prothrombin Time (sec.) } \\
\hline & & 10 & 11 & 12 & 13 & 14 & 15 & 16 & 17 & 18 & 19 & 20 & 21 & 22 & 23 & 24 & 25 \\
\hline $\begin{array}{l}\text { Two-directional } \\
\text { Comparison }\end{array}$ & $\begin{array}{l}\text { One-directional } \\
\text { Comparison }\end{array}$ & \multirow[b]{2}{*}{$\begin{array}{l}12 \\
13\end{array}$} & \multirow[b]{2}{*}{$\begin{array}{l}13 \\
14\end{array}$} & \multirow[b]{2}{*}{$\begin{array}{l}14 \\
15\end{array}$} & \multirow[b]{2}{*}{$\begin{array}{l}16 \\
17\end{array}$} & \multirow[b]{2}{*}{$\begin{array}{l}17 \\
18\end{array}$} & \multirow[b]{2}{*}{$\begin{array}{l}18 \\
19\end{array}$} & \multirow[b]{2}{*}{$\begin{array}{l}19 \\
20\end{array}$} & \multirow[b]{2}{*}{$\begin{array}{l}20 \\
22\end{array}$} & \multirow[b]{2}{*}{$\begin{array}{l}22 \\
23\end{array}$} & \multirow[b]{2}{*}{$\begin{array}{l}23 \\
24\end{array}$} & \multirow[b]{2}{*}{$\begin{array}{l}24 \\
25\end{array}$} & \multirow[b]{2}{*}{$\begin{array}{l}25 \\
27\end{array}$} & \multirow[b]{2}{*}{$\begin{array}{l}26 \\
28\end{array}$} & \multirow[b]{2}{*}{$\begin{array}{l}28 \\
29\end{array}$} & \multirow[b]{2}{*}{$\begin{array}{l}29 \\
31\end{array}$} & \multirow[b]{2}{*}{$\begin{array}{l}30 \\
32\end{array}$} \\
\hline $\begin{array}{l}1 \text { in } 20(10 \text { in } 200) \\
1 \text { in } 100(2 \text { in } 200)\end{array}$ & $\begin{array}{l}1 \text { in } 40(5 \text { in } 200) \\
1 \text { in } 200\end{array}$ & & & & & & & & & & & & & & & & \\
\hline
\end{tabular}

by more than one-fifth of the mean of both times. This type of comparison we may call "onedirectional."

An observed difference between a patient's and a control prothrombin time would thus be significant at the $5 \%$ level (in a two-directional test) or the $2 \frac{1}{2} \%$ level (in a one-directional test) if the difference exceeded 0.18 times the average of the two readings, and at the $1 \%$ level (two-directional) or $0.5 \%$ level (one-directional) if it exceeded 0.23 times the average.

Put another way, this means that, if a patient's prothrombin time exceeds 1.20 times the control reading, this is a difference which would be exceeded only once in 40 times (in that direction) or once in 20 times (in either direction) in comparisons between a normal control and another normal individual ; and that, if the patient's time exceeds 1.27 times the control reading, this difference would be exceeded only once in 200 times (in that direction) or once in 100 times (in either direction).

For facility, these multiples have been rounded off to 1.2 and 1.3 respectively and the values obtained which correspond to various control prothrombin times between 10 and $25 \mathrm{sec}$. have been tabulated. If the test plasma exceeds either of the given values corresponding to the observed control, then it may be considered abnormal with the degree of probability attached.

\section{Method}

Select the column corresponding to the observed control time: then, in a series of 200 comparisons between paired plasmas from a control and another normal subject, five subjects would be expected to give prothrombin times longer than the value given in the middle row, but only one longer than the value in the bottom row. If two-directional comparisons are required the shorter time should be entered along the top (control) line, and the longer time compared with the tabulated entry.

The tabulated entries are rounded to the nearest second. More accuracy and intermediate values may be obtained by multiplying the observed control time by 1.20 and 1.27 for the one-directional 1 in 40 and 1 in 200 risks, respectively.

Example: Control readings, 17.2, 17.6 sec., mean $17.4 \mathrm{sec}$. Longest normal reading expected at 1 in 40 risk (one-directional):

(a) from Table; col. headed 17 sec., $5 \%$ reading, 20 sec.

(b) by calculation; $17.4 \times 1.20=20.9 \mathrm{sec}$. Patient's readings, 20.8, $21.4 \mathrm{sec}$., mean $21.1 \mathrm{sec}$. At these risks this should be considered just abnormal.

REFERENCE

Armitage, P., and Ingram, G. I. C. (1958). Appl. Statist., 7, 1. 